\title{
Ruokinnan keinot sianlannan fosforipitoisuuden alentamiseksi
}

\author{
Kirsi Partanen ${ }^{1)}$, Maija Karhapää ${ }^{1)}$, Liisa Voutila ${ }^{1)}$ ja Kari Ylivainio ${ }^{2)}$ \\ ${ }^{1)}$ MTT, Kotieläintuotannon tutkimus, Tervamäentie 179, 05840 Hyvinkää, kirsi.partanen[at]mtt.fi \\ ${ }^{2)}$ MTT, Kasvintuotannon tutkimus, 31600 Jokionen, kari.ylivainio[at]mtt.fi
}

\section{Tiivistelmä}

Vesiensuojelun tavoitteet edellyttävät maataloudelta vesistöjä rehevöittävän ravinnekuormituksen vähentämistä. Kotieläintiloilla tämä tarkoittaa peltoviljelyyn ja lannan käsittelyyn kohdistuvien toimenpiteiden lisäksi eläinten ruokinnan optimointia niin, että lantaan siirtyy mahdollisimman vähän ravinteita. Sianlannan fosforipitoisuuden minimoimiseksi tarvitaan tietoa sikojen ravinnontarpeesta eri tuotantovaiheissa, käyttökelpoisen fosforin määrästä eri rehuissa ja fytaasivalmisteiden tehokkuudesta. Tämä kirjoitus käsittelee MTT:n Ympäristöä säästävä sikojen ruokinta -hankkeen tutkimuksia ruokinnan mahdollisuuksista vähentää sianlantaan erittyvän fosforin määrää, ja ruokinnan vaikutuksista helposti huuhtoutuvan fosforin määrään sian lannassa.

Fosfori varastoituu kasvien siemeniin pääasiassa fytiinihappona, jota yksimahaisten eläinten ruuansulatusentsyymit eivät juuri pysty pilkkomaan. Viljojen fosforista $72-95 \%$ oli sitoutuneena fytiinihappoon, ja fytiinihapon pitoisuus korreloi positiivisesti fosforipitoisuuden kanssa. Vehnässä ja ohrassa oli luontaista fytaasia joka edesauttaa fytiinihapon pilkkoutumista sian ruuansulatuskanavassa. Kaurassa, palkoviljoissa ja lämpökäsitellyissä valkuaisrehuissa fytaasiaktiivisuutta ei löytynyt juuri lainkaan. Sianrehujen fosforipitoisuudet vaihtelevat $4-7 \mathrm{~g} / \mathrm{kg} \mathrm{KA}$, ja niissä on fytaattifosforia 2,5 - 3 g/kg KA raaka-aineista ja rehuseoksen käyttötarkoituksesta riippuen.

Rehujen fosforin käyttökelpoisuutta sioille arvioidaan usein fosforin näennäisen kokonaissulavuuden perusteella. Siihen vaikuttavat sekä rehun fytiinihappopitoisuus että luontaisen fytaasin aktiivisuus. Luontaisen fytaasin ansiosta varsinkin vehnän, mutta myös ohran fosforin sulavuus paranee, kun viljaa ei lämpökäsitellä. Rehuoptimoinnin helpottamiseksi mikrobifytaasin sulavuusvaikutuksen arviointiin on annettu erilaisia muuntokerotoimia, mutta ne vaihtelevat suuresti ei lähteiden välillä. Fytaasin vaikutus fosforin sulavuuteen ei ole suoraviivaista, ja sulavuuden muutos pienenee fytaasiannoksen kasvaessa. Erilaiset fytaasit ovat vaikutukseltaan hieman erilaisia, ja niiden tehoon vaikuttavat myös rehujen fytiinihappopitoisuus ja muut ominaisuudet. Niinpä monien fytaasivalmisteiden vaikutusten laittaminen samalle asteikolle ruokinnan suunnittelua varten ei ole helppoa.

Sikojen fosforin tarve voidaan määrittää empiirisesti tuotantokokeiden avulla tai laskea faktoriaalisesti elintoimintojen ylläpitoon ja tuotantoon eli kasvuun, jälkeläisten tuottamiseen ja maidontuotantoon tarvittavan fosforimäärän summana. Tulevaisuudessa eläinaineksen ominaisuudet on todennäköisesti otettava huomioon fosforisuosituksia annettaessa, jotta lannan ravinnepitoisuuksien minimointiin tähtäävä ruokinta ei vaaranna luuston kehitystä ja riittävää lujuutta.

Sikojen ravinnontarpeen mukaan muuttuva monivaiheinen ruokinta alentaa lannan fosforipitoisuutta $5-10 \%$. Vaiheruokinnan mahdollisuuksia ei ole kuitenkaan vielä täysin hyödynnetty. Tilakyselyn perusteella lihasioilla oli 1-, 2- ja 3-vaiheruokinta 37, 49 ja 23 \% vastanneista. Emakoiden ruokinnassa 81 \% käytti erillisiä tiineys- ja imetysrehuja. Yleisimmät vaiheruokinnan käytön esteet olivat jatkuvatäyttöiset osastot ja riittämätön rehujen varastotila. Fosfaattien huikea hinnannousu on vasta viime vuosina laajentanut fytaasin käytön lähes kaikkiin sikojen täysrehuihin ja myös täydennysrehuihin. Fytaasilla voidaan korvata osa sianrehujen fosfaatista sikojen kasvun, liikuntakyvyn ja luiden lujuuden pysyessä hyvinä, ja se alentaa lannan fosforipitoisuutta 20 - 30 \%. Yli 80-kiloisten lihasikojen rehussa fosfaattia ei tarvita välttämättä lainkaan, kun rehussa on fytaasia.

Mitä alemmaksi sianrehujen fosforipitoisuus saadaan laskettua, sitä vähemmän lannassa myös on fosforia. Vesiuuttoisen fosforin katsotaan ennustavan lantafosforin huuhtoutumisalttiutta. Sianlannan fosforista noin $90 \%$ oli epäorgaanista fosforia. Rehun fosfaattipitoisuus ei vaikuttanut vesiuuttoisen fosforin määrään lannassa, mutta rehun kalsium-fosforisuhteen suurentaminen pienensi sitä. Fosfaatin osittainen korvaaminen fytaasilla alensi selvästi sonnan fosforipitoisuutta ja vähensi helppoliukoisen fosforin määrää. Helppoliukoista fosforia oli hieman enemmän liemimäisiä viljavalkuaisrehuja sisältäneillä ruokinnalla kuin ohra-soijaruokinnoilla. Maaperän happamuudesta riippuen osa hitaasti liukenevasta fosforista voi siirtyä helppoliukoiseen fraktioon ja siten altistua huuhtoutumiselle.

Asiasanat: sika, ruokinta, fosfori, fytaasi, lanta, Hedleyn fraktiointi 


\section{Johdanto}

Vesiensuojelun valtakunnalliset tavoitteet edellyttävät maataloudelta vesistöjä rehevöittävän ravinnekuormituksen vähentämistä kolmanneksella vuoteen 2015 mennessä verrattuna vuosien 2001 - 2005 kuormitukseen, ja pitkän aikavälin tavoitteena on ravinnekuormituksen puolittaminen (Ympäristöministeriö 2007). Elintarvikeketjun on laskettu aiheuttavan 57 \% vesistöjen rehevöitymisestä, ja 67 \% fosforihuuhtoutumista (Virtanen ym. 2009). Kotieläintiloilla peltoviljelyyn ja lannan käsittelyyn kohdistuvia toimenpiteitä ei pidetä riittävinä vähentämään vesistöjen ravinnekuormitusta. Tuotannosta tulevalle lantamäärälle on oltava riittävästi peltoalaa lannan hyödyntämiseksi kasvintuotannossa, ja eläinten ruokinta on suunniteltava niin, että lantaan siirtyy mahdollisimman vähän ravinteita.

Ravinnontarpeen mukaan muuttuva monivaiheinen ruokinta ja kasviperäisten rehujen fytaattifosforin hyväksikäyttöä parantavan fytaasientsyymin lisääminen sianrehuihin ovat tehokkaita ja käytössä olevia toimia alentaa sianlannan ravinnepitoisuuksia ja vähentää fosfaattien lisäystarvetta sianrehuihin. Sikojen fosforiruokinnan optimoimiseksi tarvitaan tietoa sikojen ravinnontarpeesta eri tuotantovaiheissa, sialle käyttökelpoisen fosforin määrästä eri rehuissa sekä fytaasivalmisteiden tehokkuudesta ja siihen vaikuttavista tekijöistä. Lannan ravinnepitoisuuksien vähentämistavoitteiden lisäksi tarvitaan tietoa ruokinnan vaikutuksesta lannan fosforin helppouteen huuhtoutua pelloilta. Tämä kirjoitus käsittelee MTT:n Ympäristöä säästävä sikojen ruokinta -hankkeen tutkimuksia ruokinnan mahdollisuuksista vähentää fosforin eritystä sianlantaan ja ruokinnan vaikutuksista helppoliukoisen fosforin määrään lannassa.

\section{Rehujen fosfori ja sen käyttökelpoisuus sialle}

\section{Fosfori ja fytiinihappo}

Fosfori varastoituu kasvien siemeniin pääasiassa fytiinihappona (myo-inositoliheksafosfaatti, $\mathrm{IP}_{6}$ ), jota yksimahaisten eläinten ruuansulatusentsyymit eivät juuri pysty pilkkomaan. Fytiinihappo esiintyy kasveissa pääasiassa K- ja Mg-suoloina eli fytaatteina, ja se muodostaa helposti komplekseja muidenkin positiivisesti varautuneiden ionien kuten $\mathrm{Ca}^{2+}, \mathrm{Zn}^{2+}$ ja $\mathrm{Fe}^{2+}$ kanssa. Viljojen ja valkuaisrehujen fosforista yleensä yli puolet, mutta jopa yli 90 \% voi olla fytaattifosforia (Selle ja Ravindran 2008). Taulukossa 1 on vuoden 2009 vilja- ja valkuaisrehunäytteistä määritettyjä fosfori- ja fytiinihappopitoisuuksia, jotka määritettiin ICP:llä (Luh Hung ja Schutte 1985, Plaami ja Kumpulainen 1991). Fytaattifosforin osuus kokonaisfosforista on laskettu fytiinihapon fosforipitoisuuden $(28,2 \%)$ avulla.

Taulukko 1. Rehujen fosfori- ja fytiinihappopitoisuus, fytaattifosforin osuus ja luontaisen fytaasin aktiivisuus.

\begin{tabular}{llllll}
\hline & $\mathrm{N}$ & $\begin{array}{l}\mathrm{P} \\
(\mathrm{g} / \mathrm{kg} \mathrm{KA})\end{array}$ & $\begin{array}{l}\text { Fytiinihappo } \\
(\mathrm{g} / \mathrm{kg} \mathrm{KA})\end{array}$ & $\begin{array}{l}\text { Fytaatti-P / } \\
\text { Kokonais-P }\end{array}$ & $\begin{array}{l}\text { Luontainen fytaasi } \\
\text { (U/kg KA) }\end{array}$ \\
\hline Ohra & 17 & $3,4 \pm 0,2(3,0-3,7)$ & $9,5 \pm 0,8(7,8-11,1)$ & $0,79 \pm 0,05$ & $587 \pm 136(413-887)$ \\
Vehnä & 9 & $3,7 \pm 0,4(3,1-4,5)$ & $11,0 \pm 1,5(8,4-13,6)$ & $0,84 \pm 0,07$ & $786 \pm 145(589-1061)$ \\
Kaura & 13 & $3,4 \pm 0,2(3,1-3,7)$ & $10,1 \pm 0,6(9,5-11,1)$ & $0,83 \pm 0,03$ & $16 \pm 17(0-51)$ \\
Herne & 2 & $3,9 \pm 0,7(3,4-4,5)$ & $10,2 \pm 2,4(8,4-11,9)$ & $0,72 \pm 0,04$ & $0 \pm(0-0)$ \\
Härkäpapu & 5 & $5,7 \pm 0,3(5,7-6,1)$ & $16,3 \pm 1,7(14,3-17,8)$ & $0,80 \pm 0,05$ & $7 \pm 7(0-15)$ \\
Rypsin siemen & 2 & $7,0 \pm 0,2(6,8-7,1)$ & $23,5 \pm 0,2(23,4-23,6)$ & $0,95 \pm 0,03$ & $18 \pm 25(0-35)$ \\
Rypsipuriste & 2 & $11,3 \pm 1,1(10,5-12,0)$ & $32,4 \pm 1,8(31,1-33,7)$ & $0,81 \pm 0,03$ & $12 \pm 3(10-14)$ \\
Rypsirouhe & 1 & 11,0 & 31,6 & 0,81 & 38 \\
Soijarouhe & 1 & 6,4 & 16,9 & 0,74 & 48 \\
\hline
\end{tabular}

Viljojen fosforipitoisuudet vaihtelivat 3,0 - 4,5 g/kg KA. Ohrassa ja kaurassa oli fosforia keskimäärin 3,4 g/kg KA ja vehnässä 3,7 g/kg KA. Viljojen fosforista 72 - $95 \%$ oli sitoutuneena fytiinihappoon. Fytaattifosforin osuus oli vehnässä ja kaurassa hieman suurempi kuin ohrassa. Härkäpavussa oli enemmän fosforia kuin herneessä, lisäksi härkäpavun fosforista suurempi osa oli fytaatteina. Rypsissä ja varsinkin siitä tehdyssä rouheessa ja puristeessa on runsaasti fosforia, ja siitä suurempi osa fytaatteina soijarouheen fosforiin verrattuna. Sekä viljojen että valkuaisrehujen fytaattifosforin osuudet olivat hieman suurempia verrattuna mm. INRA-AFZ:n (2002) rehutaulukoissa ja viime vuosien tutkimuksissa esitettyihin osuuksiin (Pontoppidan ym. 2007, Steiner ym. 2007, Selle ja Ravindran 2008). Tähän voivat vaikuttaa mm. erilaiset fytiinihapon määritysmenetelmät (Selle ja Ravindran 2008, Wu 
ym. 2009). Rautasaostusmenetelmä, jota näiden näytteiden analysoinnissa käytettiin, ei pysty erottelemaan eri inositolifosfaatteja $\left(\mathrm{IP}_{1}-\mathrm{IP}_{6}\right)$ toisistaan. Lisäksi fytiinihapon määrä vaihtelee lajikkeiden välillä ja siihen vaikuttavat kasvuolosuhteet eri vuosina (Steiner ym. 2007, Wang ym. 2010).

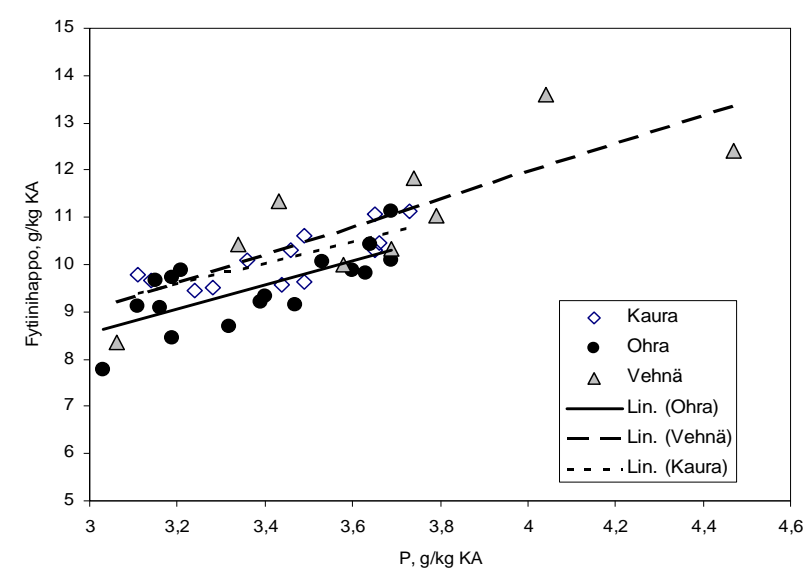

Kuvio 1. Viljojen fosforin ja fytiinihapon välinen yhteys.

Viljojen fytiinihapon pitoisuus korreloi positiivisesti fosforipitoisuuden kanssa (kuvio 1). Fytaattifosforin osuus kokonaisfosforista pysyi melko samansuuruisena fosforipitoisuuden kasvaessa. Tässä pienessä aineistossa ei havaittu riippuvuuksia viljojen hehtolitrapainon tai kemiallisen koostumuksen ja fosfori- ja fytiinihappopitoisuuksien välillä. Sianrehujen fosforipitoisuudet vaihtelevat 4 $7 \mathrm{~g} / \mathrm{kg}$ KA välillä, ja niissä on fytaattifosforia 2,5 - $3 \mathrm{~g} / \mathrm{kg}$ KA raaka-aineista ja rehuseoksen käyttötarkoituksesta riippuen. Täysrehuissa on vähemmän fosforia kuin viljatiiviste- ja komponenttiruokinnoilla.

\section{Luontaisen fytaasin aktiivisuus}

Kasvien siemenissä on luontaista fytaasi-entsyymiä, joka auttaa fytiinihappoa pilkkoutumista sian ruuansulatuskanavassa (Rapp ym. 2001). Luontainen fytaasi menettää kuitenkin aktiivisuuttaan mahan happamissa olosuhteissa helpommin kuin mikrobifytaasit (Selle ja Ravindran 2008). Luontaisen fytaasin aktiivisuudessa on eroja sekä viljojen että valkuaiskasvien välillä (Steiner ym. 2007). Taulukon 1 rehujen fytaasiaktiivisuudet määritettiin MTT:n laboratoriossa ISO 30024:29 -menetelmällä. Vehnän ja ohran fytaasiaktiivisuudet olivat pienempiä aikaisempiin tutkimuksiin verrattuna (Steiner ym. 2007, Selle ja Ravindran 2008), ja kaurassa ja palkoviljoissa ei ollut fytaasiaktiivisuutta juuri lainkaan (aktiivisuudet $<50 \mathrm{U} / \mathrm{kg} \mathrm{KA}$ ). Näissä rehuissa on aikaisemminkin havaittu vehnää ja ohraa selvästi pienempiä fytaasiaktiivisuuksia (Steiner ym. 2007, Selle ja Ravindran 2008). Luontainen fytaasi tuhoutuu herkästi lämpökäsittelyssä (Selle ja Ravindran 2008) ja osa viljojen ja palkoviljojen fytaasiaktiivisuudesta on voinut hävitä sadonkorjuun jälkeisen lämminilmakuivauksen seurauksena.

\section{Fosforin sulavuus ja fytaasin vaikutus sulavuuteen}

Rehujen fosforin käyttökelpoisuutta sioille arvioidaan useimmiten fosforin näennäisen kokonaissulavuuden perusteella. Siihen vaikuttavat sekä rehun fytiinihappopitoisuus että luontaisen fytaasin aktiivisuus (Oryschak 2005, Selle ja Ravindran 2008). Luontaisen fytaasin ansiosta varsinkin vehnän, mutta myös ohran fosforin sulavuus paranee, kun viljaa ei lämpökäsitellä (vehnä $28=>50 \%$, ohra $30=>$ $43 \%$, www.infosvin.dk). Kuivaamattoman ohran ja vehnän varastointi tiloilla joko ilmatiiviisti tai murskesäilöttynä vähentää fosfaattien lisäystarvetta sianrehuihin.

Rehuoptimoinnin helpottamiseksi fytaasin sulavuusvaikutuksen arviointiin on annettu erilaisia muuntokerotoimia, mutta ne vaihtelevat suuresti ei lähteiden välillä (Selle ja Ravindran 2008). Fytaasin vaikutus fosforin sulavuuteen ei ole suoraviivaista, ja fosforin sulavuuden muutos pienenee fytaasilisäysten kasvaessa. INRA-AFZ:n (2002) mukaan alle 250, 250 - 500, 500 - 750 ja 750 - 1000 FTU/kg fytaasia vapauttavat rehusta sulavaa fosforia $0,196,0,104,0,052$ ja $0,028 \mathrm{~g}$ fosforia 100 fytaasiyksikköä kohti. Oryschakin (2005) mukaan fytaasin fosforin sulavuutta parantava vaikutus voidaan laskea kaavalla $\left[0.334 \times\right.$ FTU $\left.-0.0001297 \times \mathrm{FTU}^{2}\right] / 10$. Tanskalaisen rehutaulukon mukaan fytaasilisien vaikutus on erisuuruinen eri raaka-aineilla (www.infosvin.dk, kuviot $2-3$ ).

Kaupallisia fytaasivalmisteita on lukuisia ja ne sisältävät eri mikrobeilla (Aspergillus niger, Trichoderma reesei, Escherichia coli, Peniophora lycii) tuotettuja fytaaseja, jotka ovat fytiinihapon fosfaattien pilkkomisen alkamiskohdan mukaan joko 3- tai 6-fytaaseja. Erityyppiset fytaasit ovat vaikutukseltaan hieman erilaisia, ja rehujen fytiinihappopitoisuus ja muut ominaisuudet vaikuttavat fytaasien kykyyn parantaa fosforin sulavuutta. Eri fytaasivalmisteiden vaikutusten laittaminen samalle mitta-asteikolle ruokinnan suunnittelua varten ei ole helppo tehtävä. Tanskalaisissa rehutaulukoissa eri fytaasien sulavuusvaikutus on laitettu samalle asteikolle ns. standardiannoksen (100 \% kuvioissa 2 3) avulla. Se vastaa 500 FTU Phyzyme- tai Natuphos-fytaasia tai 750 FTU Ronozyme-P -fytaasia. 

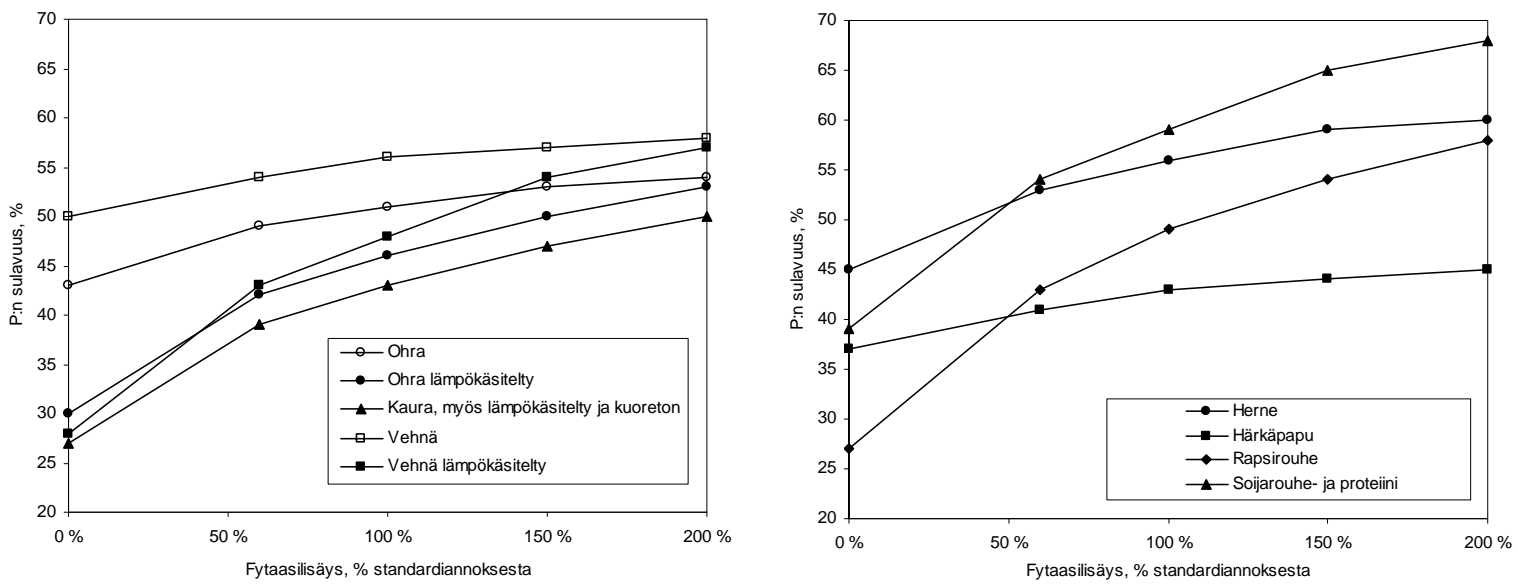

Kuviot 2 - 3. Kasvavien fytaasilisäysten vaikutus rehujen fosforin sulavuuteen (www.infosvin.dk).

\section{Sikojen fosforin tarve}

Sikojen fosforin tarve voidaan määrittää empiirisesti tuotantokokeiden avulla tai laskea faktoriaalisesti elintoimintojen ylläpitoon ja tuotantoon eli kasvuun, jälkeläisten tuottamiseen ja maidontuotantoon tarvittavan fosforimäärän summana. Siat tarvitsevat elintoimintojen ylläpitoon fosforia $10 \mathrm{mg} / \mathrm{pv}$ elopainokiloa kohti (Jondreville ja Dourmad 2005). Fosforin tarve kasvuun lasketaan elimistöön pidättyneen fosforin määrästä. Jondrevillen ja Dourmadin (2005) mukaan sian fosforipitoisuus voidaan laskea sen elopainosta (EP) kaavalla: $-0,002857 \times \mathrm{EP}^{2}+5,4199 \times \mathrm{EP}$, ja sulavan fosforin tarve vastaa sian kasvuun pidättynyttä fosforimäärää. Kuvioon 4 on laskettu edellä kuvatun faktoriaalisen laskutavan mukaan esimerkiksi lihasikojen fosforin tarve 25 - $120 \mathrm{~kg}$ painovälillä. Tarve rehuyksikköä kohti on saatu jakamalla päivätarve lihasikojen vapaalla rehun syönnillä (Tuori ym. 2006). Laskelma vastaa hyvin empiiristen fosforintarvekokeiden perusteella (Partanen 2006) annettuja lihasikojen sulavan fosforin suosituksia, jotka ovat 25 - $55 \mathrm{~kg}$ painossa 2,7 g/ry, 55 - $80 \mathrm{~kg}$ painossa 2,4 g/ry ja yli $80 \mathrm{~kg}$

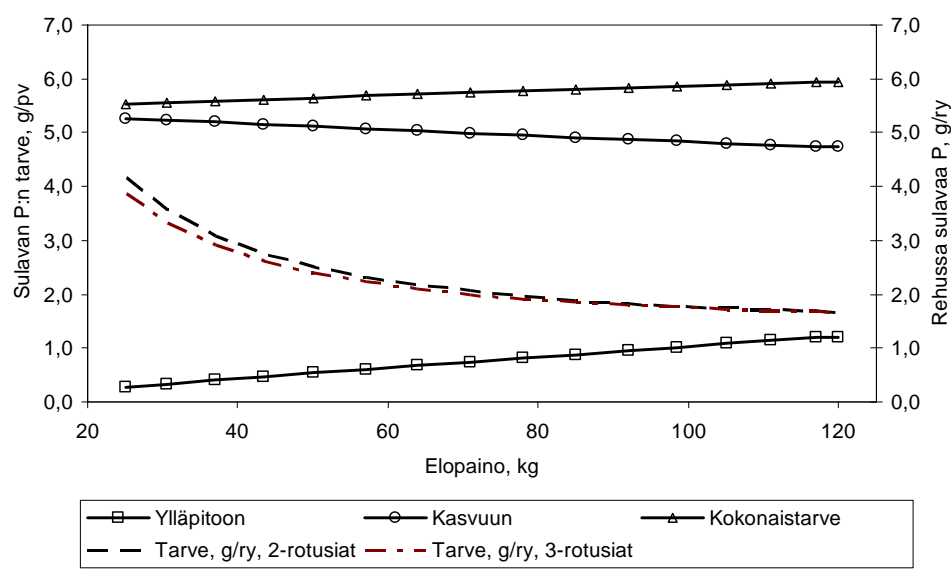

Kuvio 4. Lihasikojen sulavan fosforin tarve faktoriaalisesti laskettuna. painossa 1,9 g/ry (MTT 2006). Alexanderin ym. (2008) mukaan nopeasti kasvavaksi ja lihaksikkaaksi jalostettujen sikojen luut reagoivat voimakkaammin niukkaan fosforin saantiin kuin hitaammin kasvavien ja rasvaisempien sikojen luut. Tulevaisuudessa sikojen kasvukyky ja lihakkuus on todennäköisesti otettava huomioon fosforisuosituksia annettaessa, jotta lannan ravinnepitoisuuksien minimointiin tähtäävä ruokinta ei vaaranna luuston kehitystä ja riittävää lujuutta.

\section{Ruokinnan mahdollisuudet sianlannan fosforipitoisuuden alentamiseksi}

\section{Monivaiheinen ruokinta}

Sikojen ravinnontarpeen mukaan muuttuva monivaiheinen ruokinta on keskeinen keino alentaa sianlannan fosforipitoisuutta. Oryschakin (2005) mukaan vaiheruokinnalla saadaan alennettua sianlannan fosforipitoisuutta 5 - $10 \%$. Vaiheruokinnan mahdollisuuksia ei ole vielä täysin hyödynnetty suomalaisilla sikatiloilla. Kesällä 2008 tehdyn sikatilojen ruokintakäytäntöjä selvitettäneen kyselyn perusteella 37 \%:lla vastanneista oli lihasioilla yksivaiheruokinta, 49 \%:lla kaksivaiheruokinta ja 23 \%:lla kolmivaiheruokinta. Emakoiden ruokinnassa 81 \% käytti erillisiä tiineys- ja imetysrehuja ja vain $19 \%$ syötti samaa rehua tuotantovaiheesta riippumatta. Kyselyyn vastasi 42 tilaa, joista $43 \%$ oli emak- 
kosikala, 31 \% yhdistelmäsikala ja 26 \% lihasikala. Tiloilla oli keskimäärin 277 emakkoa (30 - 1800), jotka tuottivat 22,9 vieroitettua porsasta per vuosi. Lihasikapaikkoja oli keskimäärin 758 kpl (50 2400). Yhdistelmätuotannossa kolmannes vastanneista käytti emakoille ja lihasioille yhdistelmätiivistettä, mistä lihasiat saavat fosforia jopa 1,5-kertaisesti tarpeeseen nähden. Yleisimmät esteet monivaiheisen ruokinnan käytölle olivat jatkuvatäyttöiset osastot, riittämätön varastotila eri rehuille, sikalan pienuus ja työmäärän lisääntyminen. Tärkeimmät syyt monivaiheisen ruokinnan käytölle olivat pienemmät rehukustannukset, paremmat tuotantotulokset ja eläinten hyvinvoinnin edistäminen. Vain pieni osa vastanneista piti vaiheruokinnan etuna pienempiä typpi- ja fosforipäästöjä. Ruokintatekniikan kehittymisen myötä jopa viikoittain vaihtuva ruokinta on tullut mahdolliseksi toteuttaa, kun osastot ovat kertatäyttöisiä. Osa tiloista käyttää jo nyt useampaa kuin kolmea rehuseosta sekä porsaiden että lihasikojen kasvatukseen.

\section{Fytaasin käyttö ja lihasikojen fosfaatiton loppuruokinta}

Kaupallisia fytaaseja on ollut markkinoilla vuodesta 1991 alkaen (Selle ja Ravindran 2008), ja niitä alettiin Suomessakin käyttää lihasikojen täysrehuissa 1990-luvun puolivälissä. Fytaasin käytöllä voidaan alentaa lannan fosforipitoisuutta keskimäärin 20 - 30 \% (Oryschak 2005). Kuitenkin vasta viime vuosina koettu fosfaattien huikea hinnannousu on laajentanut fytaasin käytön lähes kaikkiin sikojen täysrehuihin ja myös täydennysrehuihin (tiivisteet). Fytaasin käytön laajentaminen on vähentänyt fosfaattien käyttöä sianrehujen valmistuksessa noin 30 \% vuoden 2008 alusta (E. Helander, Suomen Rehu). Osaltaan fytaasien käyttöä lisää ja niiden tehon luotettavuutta parantaa entistä tehokkaampien ja lämpökäsittelyä (rakeistus) hyvin kestävien fytaasien tulo markkinoille.

Lihasikojen syömästä rehusta noin 40 \% kuluu loppukasvatuksen (80 kg - teurastus) aikana, jolloin sika voisi päräjätä nykyistä suositusta hieman pienemmälläkin sulavan fosforin määrällä (O’Quinn et al. 1997, Partanen \& Volanto 2007). Tarve lähes täyttyy ilman fosfaattilisää, kun sikoja ruokitaan runsaasti fosforia sisältävillä sivutuoterehuilla, kuten ohravalkuaisrehulla. Taulukon 2 tutkimuksessa ohraa ja soijarouhetta tai ohraa ja ohravalkuaisrehua (OVR) sisältäneiden ruokintojen monokalsiumfosfaatista osa korvattiin lisäämällä alku- ja keskikasvatusrehuihin 500 FTU/kg fytaasia. Loppukasvatusrehuihin ei lisätty lainkaan fosfaattia, ja rehuja syötettiin sekä ilman fytaasia että fytaasin kanssa. Kontrollina oli monokalsiumfosfaatilla terästetyt ruokinnat, jossa oli sulavaa fosforia em. ruokintasuositusten mukaisesti 2,7, 2,4, ja 1,9 g/ry.

Taulukko 2. Fosfaatin käytön vähentämisen vaikutukset lihasikojen ohra-soija- ja ohra-ohravalkuaisrehupohjaisilla ruokinnoilla.

\begin{tabular}{|c|c|c|c|c|c|c|}
\hline Ruokinta & 1 & 2 & 3 & 4 & 5 & 6 \\
\hline Raaka-aineet & \multicolumn{3}{|c|}{ Ohra-soija } & \multicolumn{3}{|c|}{ Ohra-Farmarin OVR } \\
\hline 1- ja 2-rehu: & Fosfaattia & \multicolumn{2}{|c|}{ Väh. fosfaattia + fytaasi } & Fosfaattia & \multicolumn{2}{|c|}{ Väh.fosfattia + fytaasi } \\
\hline Sulava P. g/ry & $2,7 / 2,4$ & \multicolumn{2}{|c|}{$2,7 / 2,4$} & $2,7 / 2,4$ & \multicolumn{2}{|c|}{$2,7 / 2,4$} \\
\hline 3-rehu & Fosfaattia & Fosfaatiton & $\begin{array}{l}\text { Fosfaatiton } \\
+ \text { fytaasi }\end{array}$ & Fosfaattia & Fosfaatiton & $\begin{array}{c}\text { Fosfaatiton } \\
\text { + fytaasi }\end{array}$ \\
\hline Sulava P, g/ry & 1,9 & 1,1 & 1,7 & 1,9 & 1,5 & 2,1 \\
\hline Kasvu, g/pv & 950 & 983 & 980 & 937 & 916 & 957 \\
\hline Rehua, ry/kg & 2,61 & 2,52 & 2,52 & 2,67 & 2,72 & 2,60 \\
\hline Luun murtolujuus & 119 & 91 & 102 & 113 & 83 & 104 \\
\hline Rehujen P, kg/sika & 2,1 & 1,6 & 1,5 & 2,0 & 1,7 & 1,6 \\
\hline Fosfaattia, kg/sika & 3,1 & 0,8 & 0,8 & 1,6 & 0,2 & 0,2 \\
\hline
\end{tabular}

Tulosten perusteella osa rehuseosten monokalsiumfosfaatista voidaan korvata fytaasilla. Yli 80kiloisten lihasikojen rehussa, jonka pääraaka-aineina ovat ohra ja soijarouhe, rehufosfaattia ei tarvita välttämättä lainkaan, kun rehussa on fytaasia $500 \mathrm{FTU} / \mathrm{kg}$. Ohra-OVR ruokinnalla lisätyn fosfaatin jättäminen pois loppukasvatusrehusta heikensi hieman sikojen liikuntapisteitä fytaasilisästä huolimatta. Tähän voi olla syynä OVR:n fosforipitoisuduen vaihtelu kokeen aikana tai sen fosforin sulavuuden arvioiminen liian hyväksi. Tämän vuoksi OVR-ruokinnssa on hyvä käyttää hieman lisättyä fosfaattia turvamarginaalina. Sikojen syömä fosforimäärä pieneni fytaasin ja fosfaatittoman loppuruokinnan ansiosta noin 0,5 kg per sika, ja sianlantaan joutuvan fosforin määrä vähenee vastaavasti. 


\section{Ruokinnan vaikutus sianlannan fosforin liukoisuuteen}

Mitä alemmaksi sianrehujen fosforipitoisuutta saadaan laskettua, sitä vähemmän lannassa myös on fosforia. Kuvioissa $6-8$ on esitetty lihasikojen ruokintakokeissa kerätyistä sontanäytteistä Hedleyn fraktiointimenetelmän mukaan (Sharpley ja Moyer 2000) määritettyjä fosforin liukoisuuksia. Fraktioista vesiuuttoisen fosforin katsotaan ennustavan lantafosforin huuhtoutumisalttiutta (Sharpley ja Moyer 2000 ). Sianlannan fosforista noin 90 \% oli epäorgaanista fosforia. Lihasikojen alku- ja loppukas-

Alkukasvatuskoe 25 - $65 \mathrm{~kg}$

Loppukasvatuskoe 55 - 115 kg

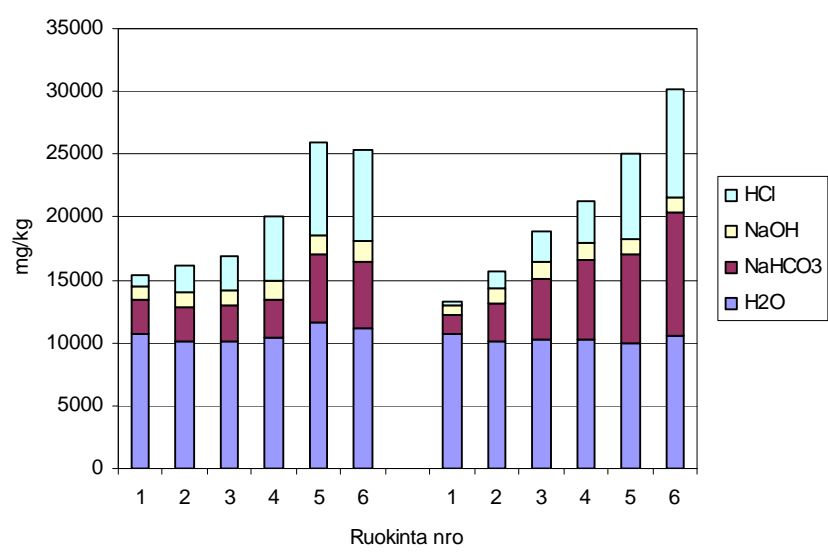
vatusrehujen fosforipitoisuuden nostaminen monokalsiumfosfaatilla (kuvio 5) ei vaikuttanut vesiuuttoisen fosforin määrään vilja-soijarouhepohjaisilla ruokinnoilla. Monokalsiumfosfaatin fosforista $74 \%$ oli vesiuutoista. Rehun kalsium-fosforisuhteen suurentaminen 1:1:stä 1,6:een pienensi vesiuuttoisen fosforin määrää (kuvio 6). Vesiuuttoista fosforia oli enemmän vehnävalkuaisrehua ja heraa sisältäneillä liemiruokinnoilla kuin rakeistetulla ohrasoijaruokinnalla.

Kuvio 5. Sonnan fosforin liukoisuus Hedleyn fraktioinnin mukaan, kun rehuissa on kasvava määrä monokalsiumfosfaattia (alkukasvatus: 0,1 - 2,35 \% ja loppukasvatus: 0,08 - 3,01 \%)

Fosfaatin osittainen korvaaminen fytaasilla alensi selvästi sonnan fosforipitoisuutta ja vähensi helppoliukoisen vesiliukoisen fosforin märäää (kuvio 7), mutta helppoliukoisen fosforin suhteellinen osuus suureni hieman. Tässäkin kokeessa vesiliukoista fosforia oli hieman enemmän liemimäistä ohravalkuaisrehua sisältäneellä ruokinnalla kuin ohra-soijaruokinnalla. Fosforin liukoisuus määritettiin kuivaamattomasta sonnasta, minkä vuoksi helppoliukoista fosforia oli enemmän kuin edellä olevien kokeiden kuivatuista sontanäytteistä määritettynä. Maaperän happamuudesta riippuen osa hitaasti liukenevasta fosforista voi siirtyä helppoliukoiseen fraktioon ja siten altistua huuhtoutumiselle (Ylivainio ym. 2008).

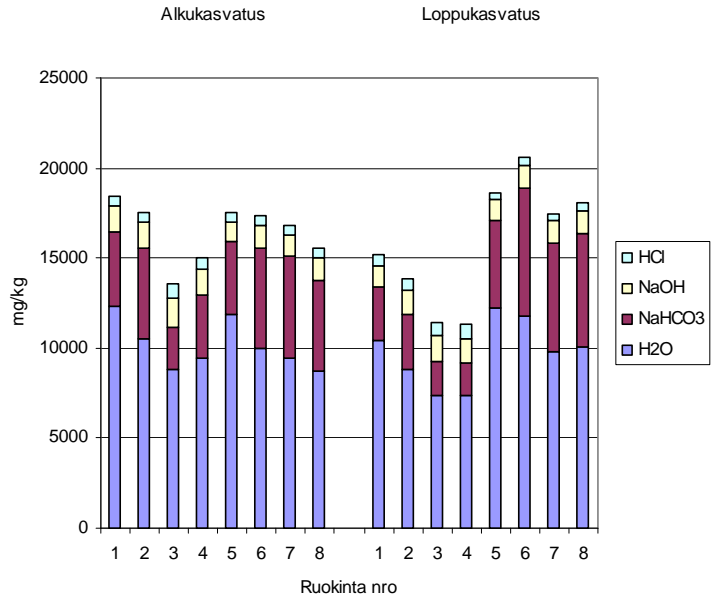

Kuvio 6. Rehun raaka-ainekoostumuksen $(1-4=$ ohra-soijarouhe ja $5-8=$ ohra-soijarouhevehnävalkuaisrehu-hera) ja kalsium-fosforisuhteen $(1$ ja $5=1: 1,2$ ja $6=1,2: 1,3$ ja $7=1,4: 1$ ja 4 ja $8=$ $1,6: 1)$ vaikutus sian sonnan fosforin liukoisuuteen Hedleyn fraktioinnin mukaan.



Kuvio 7 Ruokinnan vaikutus sianlannan fosforin liukoisuuteen Hedleyn fraktioinnin mukaan Taulukossa 2 esitetyn lihasikojen kasvatuskokeen ruokinnoilla. 


\section{Johtopäätökset}

Sianlannan fosforipitoisuutta saadaan alennettua välttämällä fosforin yliruokintaa eli käyttämällä sikojen ravinnontarpeen muutoksia seuraavaa monivaiheista ruokintaa, valitsemalla rehuseoksiin rehuraaka-aineita, joiden fosfori on hyvin sulavaa, ja lisäämällä rehuihin kasviperäisen fosforin hyväksikäyttöä parantavaa fytaasi-entsyymiä. Käytettäessä fytaasia, yli 80 kiloiset lihasiat voidaan ruokkia jopa ilmaan epäorgaanista fosfaattia. Sianlannan fosforista noin $90 \%$ on epäorgaanista fosforia ja yli puolet on vesiliukoisena helposti huuhtoutuvaa pellolle levitettynä. Vesiliukoista fosforia on enemmän liemimäisiä viljavalkuaisrehuja syöneiden sikojen lannassa kuin vilja-soijapohjaisella ruokinnalla.

\section{Kirjallisuus}

Alexander, L.S., Qu, A., Cutler, S.A., Mahajan, A., Lonergan, S.M., Rothschild, M.F., Weber, T.E., Kerr, B.J. \& Stahl, C.H. 2008. Response to dietay phosphorus deficiency is affected by genetic background in growing pigs. J. Anim. Sci 86: 2585 - 2595.

INRA-AFZ. 2002. Tables of composition and nutritional value of feed materials. Wageningen Academic Publishers.

Jondreville, C. \& Dourmad, J.-Y. 2005. Le phosphor dans la nutrition des porcs. Prod. Anim. 18: 183 - 192.

Luh Huang, C. \& Schulte, E.E. 1985. Digestion of plant tissue for analysis by ICP emission spectrometry. Comm. Soil Sci. Plant Anal. 16: 943 - 958.

MTT. 2006. Rehutaulukot ja ruokintasuositukset. MTT:n selvityksiä 106. http://www.mtt.fi/mtts/ pdf/mtts106.pdf

O’Quinn, P.R., Knabe, D.A. \& Gregg, E.J. 1997. Digestible phosphorus needs of terminal-cross growingfinishing pigs. J. Anim. Sci. 75:1308 - 1318.

Oryschak, M. 2005. What goes in is what comes out: How feeding program influences and can influence manure nutrient content. http://www1.agric.gov.ab.ca/\$department/deptdocs.nsf/all/epw9913

Partanen, K. 2006. Kivennäistaulukot ja -suositukset uudistuvat : Ca- ja P- suosituksiin tarkennuksia. Sika 36: 9-11

Partanen, K. \& Volanto, P. 2007. Isoille lihasioille riittää vähempikin fosfori. Maaseudun Tiede 64, 1(18.6.2007): 12.

Plaami, S. \& Kumpulainen J. 1991. Determination of Phytic acid in cereals using ICP-AES to determine phosphorus. J. Assoc. Off. Anal. Chem. 74: 32 - 36.

Pontoppidan, K., Pettersson, D. \& Sandberg, A.-S. 2007. The type of thermal feed treatment influences the isositol phosphate composition. Anim. Feed Sci. Technol. 132: 137 - 147.

Rapp, C., Lantzsch, H.-J. \& Drochner, W. 2001. Hydrolysis of phytic acid by intrinsic plant and supplemented microbial phytase (Aspergillus niger) in the stomach and small intestine of minipigs fitted with reentrant cannulas. 3 . Hydrolysis of phytic acid $\left(\mathrm{IP}_{6}\right)$ and occurrence of hydrolysis products $\left(\mathrm{IP}_{5}, \mathrm{IP}_{4}, \mathrm{IP}_{3}\right.$ and $\left.\mathrm{IP}_{2}\right)$. J. Anim. Physiolo. a. Anim. Nutr. 85: 420 - 430.

Selle, P.H. \& Ravindran, V. 2008. Phytate-degrading enzymes in pig nutrition. Livest. Sci. 113: 99 - 122.

Sharpley, A.N. \& Moyer, R. 2000. Phosphorus forms in manure and compost and their release during simulated rainfall. J. Environ. Qual. 29, 1462 - 1469.

Steiner, T., Mosenthin, R., Zimmermann, B., Greiner, R. \& Roth, S. 2007. Distribution of phytase activity, total phosphorus and phytate phosphorus in legume seeds, cereals and harvest year and cultivar. Anim. Feed Sci. Technol. 133: 320 - 334.

Tuori, M., Siljander-Rasi, H. \& Partanen, K. 2008. Rehun olomuodon ja energiaväkevyyden sekä rodun ja sukupuolen vaikutus lihasikojen kasvatuksessa. In: Toim. Anneli Hopponen. Maataloustieteen Päivät 2008, 10.11.1.2008. Suomen maataloustieteellisen seuran tiedote 23: 8 p. Julkaistu 9.1.2008

Virtanen, Y., Hyvärinen, H., Katajajuuri, J.-M., Kurppa, S., Nousiainen, J., Saarinen, M., Sinkko, T., Usva, K., Virtanen, J., Voutilainen, P., Ekholm, P., Grönroos, J., Koskela, S., Väänänen, S. \& Mäenpää, I. 2009. Elintarvikeketjun ympäristövastuun taustaraportti. http://www.laatuketju.fi/laatuketju/www/fi/julkaisut/ Ketjuvastuu_kokonaisuus_15_12_2009.pdf

Wang, N., Hatcher, D.W., Warkentin, T.D. \& Toews, R. 2010. Effect of cultivar and environment on physichochemical and cooking characteristics of field pea (Pisum sativum). Food Chem. 118: 109 - 115.

Wu, P., Tian, J.-C., Walker, D.E. \& Wang, F.C. 2009. Determination of phytic acid in cereals - a brief review. Int. J. Food Sci. Technol. 44: $1671-1676$.

Ylivainio, K., Uusitalo, R., Turtola, E. 2008. Meat bone meal and fox manure as P sources for ryegrass (Lolium multiflorum) growth on a limed soil. Nutr. Cycl. Agroecosyst. 81: 267 - 278.

Ympäristöministeriö. 2007. Vesiensuojelun suuntaviivat vuoteen 2015. Valtioneuvoston periaatepäätös. Suomen Ympäristö 10 / 2007. www.ymparisto/julkaisut 